\title{
今一度, 食の安全を考える
}

山㠃裕康

\section{Why Don't You Reconfirm about “Food Safety'?}

\author{
Hiroyasu YAMAZAKI \\ Faculty of Pharmaceutical Sciences, Kobe Gakuin University, 1-1-3 Minatojima, \\ Chuo-ku, Kobe 650-8586, Japan
}

わが国では, 食の安全に係わる出来事が起こる と，消費者のみならず食品取扱い関係者間でも食の 安全確保についての関心が一時的に高まるものの, 少し時間がたてばほとんど無関心になってしまう傾 向がみられる。食の安全確保には, 法律の整備はも とより，国，地方自治体並びに登録検査機関など民 間の食品衛生担当部署の拡充と効率的な作業システ 厶運用，さらには食品取扱い関係者や消費者に対す る食の安全確保に関する正確な情報提供が極めて重 要であると言える.
特に，食料の約 $60 \%$ （カロリーベースで）を輸 入に頼っているわが国においては，輸入食品の安全 性確保が極めて重要であると言える.

本シンポジウムでは, 食の安全について, 輸入食 品検査現場における安全確保の現状と対策, 登録検 查機関が食の安全に果たす役割，食の安全確保に必 要不可欠な分析機器と分析技術の果たす役割と問題 点，そして最後に，依然として消費者の不安が消え ない食品添加物について最新情報の提供を行い，今 一度「食の安全」について考えてみたい。

神戸学院大学薬学部（干650-8586 神戸市中央区港島 1

$-1-3)$

e-mail: yamazaki@pharm.kobegakuin.ac.jp

日本薬学会第 130 年会シンポジウム S32 序文 